\title{
Albanians Have always Respected the Rules
}

\author{
Indrit Shtupi \\ PhD Candidate at the European University of Tirana \\ Cel: +355692926251/ indritshtupi@yahoo.com \\ Arjan Vasjari \\ $P h D$, Lector at the European University of Tirana \\ Cel: +355686031506/vasjaria_al@yahoo.it \\ Xhabir Zenuni \\ European University of Tirana
}

\section{Doi:10.5901/mjss.2013.v4n9p36}

\section{Abstract}

Albanians always respected laws and rules. The oldest law was the make (rules), a kind of Constitution applied by the majority of Albanians throughout the centuries and in different regions. During the unity of Prizren, Albanians made the first attempt to edit a text in the form of the Constitution. In 1913, when Albania was recognized by the major European powers, the six major powers donated its first Constitution in the name Organic Statute. After the liberation from the fascists and the communists coming of 1946 on 11 January 1946, the Constitutional Assembly declared Albania Democratic Republic solving in this way the question of the form of government. The democratic changes in 1990 pointed the way of change and reform in the constitutional law of the country with the constitution of 1991 and the 1998.

Keywords: Rules, kanun, monarch, law, statute, government, reforms, constitution.

\section{Introduction}

The decision to write this conference relies on the finding that there is full development of the issue in Greece, due to lack of knowledge of the Albanian language by Greek writers. The analysis of this issue is of great importance because Albania was state with special status. For 45 years, the state had two constitutions, which actually did not recognize any political rights to their citizens. It is important for everyone to learn the constitutional evolution of the neighboring country. This article is divided into two chapters, which analyze the constitutional steps of Albania since the establishment of the Albanian state until today.

The first part of this conference is devoted to the first Albanian constitution starting with the code "make", which regulated the relations of the citizens especially those of the north. After the Kanun was the first "Organic Statute» Albania year 1914, which was in force for only six months and enshrined the constitution of the monarchy under foreign prince. The second "Organic Statute" with constitutional force was that obtained from the conference of Lushnja, which differed from the first, because a representative instrument of national character adopted it. Later this statute extended reformulating the monarchy as a form of government. In 1925, Albania Republic proclaimed the same year adopted the Basic Law of Albanian Republic, a full constitution drafted in a single document. In 1928, Zog announced the establishment of the monarchy as a form of government. After the release of the Italian fascists, Albania adopted the Constitution of the People's Republic of Albania (Constitution of the People's Republic of Albania) which was communist in nature and in force from 16.03.1946. This Constitution enshrined the political power of working in alliance with the class of residents of the province (farmers). The Constitution of 1946 was replaced by the 1976 Constitution, which he called Albania "Democratic Socialist Republic". The aim of this Constitution was to deepen the communist character of the state and class distinction.

In the second part of the Conference are analyzes the democratic changes in 1990, which led to significant adjustments to the constitutional laws of the country. On 29.04.1991 was approved the law no.7491/1991, which established democratic parliamentary system. On 21.10.1998 was approved the current Constitution of Albania, which 
has been described by many as a modern and liberal text. Of particular importance is ensuring the Constitutional Court, an institution of Austrian-German origin. This Conference analyzes among others, the functions, powers, persons who initiate the proceedings before the Constitutional Court.

\section{The constitutional order of Albania from 1878-1990}

\subsection{Background}

1. The work of Sami Fraseri "Albania was what, what is and what will be done with it" helped the Albanian constitutional lawyers in the development of constitutional thought and various theories (Reso, R. $1978 \mathrm{pg}$. 10). The third part of this project like a written constitution (Anastasi, A. 2004 pg. 35). Fraseri was an enemy of absolutism and feudalism. He did not support the entire monarchical regime, however strongly supported the regime in which the people participate actively (Anastasi, A. 2004 pg. 5). At that time, the Albanian customary law had developed its own instruments and had special forms. These forms were collective, such as councils and the trials of elders (Luarasi, A. 1994 pg. 5). Fraseri appreciate the role of the individual, but as forms of governance rather collective forms (Reso, R. 1978 pg. 56). In his work, he cited that freedoms and rights ought to give the new country like freedom of conscience and the right to compulsory education.

2. The autonomy of local government: Fraseri presented the organization of local government as an important factor in the fate of the state and therefore devotes the third part of his work there (Frashëri, S. 1889 fq. 100). The country was divided into 15 communities, which will be divided in 3-4 kaza. Across the country, there were 15 governors and 50 lieutenant governor. Every small town would set up a council, who as supreme will governed by the general meeting composed of individuals who were the right age and fortune. The General Assembly elected village council and the judges who will be employed in the village (Anastasi, A. $2004 \mathrm{pg}$. 40).

3. Proposed political organization: The proposed policy organization in Albania had western connotation (Aurela, A. 2004 pg. 37) as head of state he envisioned a collective body the council of elders consisting of fifteen people elected by all the "hull" of the country. The board itself will elect its Chairperson and among them would apply beginning primus inter pares. Decisions would be collective, although the President would have the honor to be the first citizen of the country (Reso, R. pg. 87). Fraseri determined in a transparent way the powers of the Board and the qualifications of eligibility for membership. The responsibilities of the Council of Elders were: 1) To convene the General Council (Parliament), 2) To call in messages the General Council, 3)To appoint the government and signed the decisions, 4) To exercise its right of veto (veto) the acts approved by the General Council, 5) To direct the foreign policy of the country.

4. Bodies: The General Council (Parliament): The maximum representative body was the General Board (Anastasi, A. 2004 pg. 39). That would consist of 100 members, one member per 20,000 residents. This body would not be permanent as the council of elder (Reso, R. 1978 pg. 97-99).

5. The Cabinet: The Cabinet considered a collective body composed of independent institutions. One of the seven ministers would be the President of the cabinet. This instrument would be linked by a relationship of trust with the general council and the council of elder.

\subsection{Previous Constitutions}

\subsubsection{The Kanun}

First form of Constitution: Albanians always respected laws and rules. The oldest law was the make (rules), a kind of Constitution applied by the majority of Albanians throughout the centuries and in different regions. The origin of this term has generated discussion among Albanian writers. His father George pistachios in his introduction Lek Dukagjin expressed as follows: "The word is derived from the ancient Greek language and specifically from the word canon." Another historian believes that the word has Byzantine origin and specifically from the word 'normal' (Anastasi, A. Constitutional Law, 2004 pg. 33). Other authors argue that the term was introduced in Albania from the Turkish word "shop» (Kanuname). Make a law or collection of unwritten laws that have been passed down from generations to generations and reflect the social-economic status of the previous periods and each time protects the interests of specific social classes. They also make the totality of regulations coming from the common law. These codes regulate a wide 
sphere of social relations and the autonomous government of the people of northern Albania and heritage of IndoEuropean culture and beyond that of the Illyrians. During the Turkish Empire, these codes have been adapted to ensure self-government the Albanians.

Most known legal codes of this type was the Kanun of Lek Dukagjin (Kanuni I Leke Dukagjinit) and make the Skanderbeg (Kanuni i Skenderbeut). The first codified in the XV century by an Albanian prince of the same name, the second the XVI century. The Kanun of Lek Dukagjin served the Albanians to maintain self-government and to exercise a democratic power. Another important do was make the Lamperise (Kanuni i Laberisë).

\subsubsection{The Organic Statute of Albania 1914}

In 1878, Albanians formed the unity of the Albanians of Prizren and simultaneously created a provisional government. For this period, it is worth mentioning the new do, the program section. During the unity of Prizren, Albanians made the first attempt to edit a text in the form of the Constitution. In 1913, when Albania was recognized by the major European powers, the six major powers donated its first Constitution in the name Organic Statute. This law remained in force for a few months during 1914. The government in the coming years based on a number of uncoded laws and provisional constitution.

In recognition of the independence of Albania by the Great Powers was an agreement for a form of monarchy as a system of government. Under the Statute of 1914 Albania had royal status as king Wid (This Constitution did not resist for a long time and the reason was that Albanians were against the king and the beginning of the First World War). This statute was elaborated by the International committee, and took effect on 10.04.1914 and ratified all the major decisions taken by the Conference of Ambassadors in London, 29.07.1913. A national assembly with representative character would have legislative powers and comprising members ex officio, members elected by the people and members elected by the prince. The right choice was limited because they require the age of 30 years for voters, knowledge of writing and reading. The Organic Statute was of particular significance, because it was an organic act taken based on an independent Albania from the Turkish Empire. This statute made a step in this direction by imposing the monarchical regime in Albania. The characteristics of Incorporation were (Aurela, A. 2004 pg. 34):

1) Monarchical character. Head of state was the prince, 2) it establishes an unfinished independent state, which controlled the major powers. The statute had the form of a document destined for vassal states. 3) The Statute meant steps in establishing a liberal state in Albania, but not a fully democratic state. Recognize that private property and the free exercise of economic, political, social activities, but on the other, the right representation was limited. 4) That statute was a quasi-constitution separate from the constitutions of other Western countries. A national institution as an organ of the Albanian people approved the Statute, but it was a donation of large forces to Albania. 5) The Statute was not making a drastic break from the Turkish state and not imitated European constitutions that era.

Organization of local government: Local governments were oriented format command of the Turkish state. The Statute regulates the organization of the judiciary of the country, which would consist of 1) The council of elder, 2) They magistrates, 3) The courts of first instance, 4) The appeal. For cases in which one of the parties were alien would apply "consular jurisdiction", which was a legacy of the Turkish Empire.

\subsubsection{Lushnja Statute 1922}

The national conference Lushnja took place on 28-31 January 1920 with the participation of fifty representatives from all parts of Albania (Husi, G. pg. 10-49). The conference received significant decisions for full self-government of Albania and strengthening of the Albanian people. Decision of constitutionalising the Albanian state as a full autonomous state run by institutions that have established themselves as Albanians. Compared with the "Organic Statute of Albania" in 1914 the Statute of Lushnja was adopted by a representative organ of national character, however, remained unfinished and was not a full constitutional text (Omari, L. pg. 23).

\subsubsection{Extension of Lushnja Statute 1922}

A full Constitutional Act adopted by the National Council in 1922, which was based on "regulatory bases of the Supreme Council" called "The Statute of the Albanian state" of 1922. This association reaffirms the monarchy as a form of government in the introduction. Further stressed that the board, which belonged to the king, would remedy the royal throne temporarily. Stating clearly the distinction of the three powers (legislative, executive and judicial). Skip to content 
observed an influence of the European constitution with monarchical regime eg that of Belgium (1831) and Italy (1848). However, the statute appears features that give him an original character (Anastasi, A. pg. 44). Based on this legislative power shall belong to the council (parliament, Article 2). The people elected the council of elder for four years (Articles 59-60). Elections will be conducted based on the electoral law guaranteeing the right to vote only for men. Executive power is vested in the Board who exercised through the cabinet (Article 3). The Board consisted of four members who are elected for two years by the Board of Elder (Article 28). He was Head of State and is characterized by two fundamental characteristics: 1) collective and 2) elective.

The constitutional nature of the association took a particular form as this there were two basic principles: the irresponsible king and secondly the responsibility of ministers to Parliament. The statute accept a transparent and strict separation of powers. The statute of Lushnja 1922 represents a constitutional act democratic, national and originality while temporary and flexible format. In this thought safeguard our fundamental European democratic principles and basic human rights. Originality displays the imposition of single-member legislative power and the imposition of a prestigious council. By the possibility of revision or addition through a simple procedure, which differs from the procedure used for ordinary laws (Omari, L. 1994 pg. 40). For the approval of the latter sufficed to simple majority (The amendmends were correct when were taken with a majority of $2 / 3$ of the votes of the members of this organ).

\subsubsection{The fundamental statutes of the Republic of Albania 1925}

In 1920 the Albanians are living a period of political instability. After the triumph of his party Zog elections against the party of Fan Noli (party of revolutionaries) on 25/01/1925, Albania proclaimed democracy, to strengthen the authority of the Zog to ascend the throne. In 1925, the fundamental law of the Republic of Albania, a full constitution drafted in a single document. Democracy was based on the model of the Third French Republic (1870-1940). He was Parliamentary State led the President, who was Prime Minister of the country. The Association is comprised of 142 articles divided into four chapters. In Article 1 of the Statute was regulated that Albania is a parliamentary democracy with a head of state (The official newspaper of the state, 1925, No. 8 3.7.1925). The legislative power was dirimenise that of the parliament and parliamentarians. Two guidelines statutes were: Strengthening the independence of the new Albanian state and the imposition of a constitutional republican regime. In the Albanian literature claimed that the Albanian democracy in 1925 was a presidential republic based on U.S. model However, with an experienced and comparative glance it seems that the Albanian Constitution is more European and establishes a model similar to that of France in 1875 (Gjilani, F.1927 pg. 7). Some features of this Association were: 1) Restate basic democratic principles that were vested by statute in 1922 as the sovereignty of the state and the famous principle of separation of powers (Anastasi, A. 2004 pg. 47). 2) In Albania for first time adopters parliament consisting of two houses: The body of deputies and senators that (Article 7). The first consisted of representatives elected by indirect vote by the people every four years. The senate consisted of 18 Senators, the two thirds of which would be elected by the people under a special law and the third by the President of the Republic (Article 49). 3) The leader of democracy than the fact that Prime Minister were also supplied with wide-ranging responsibilities, which will envy the President of America. 4) The Albanian government was continental. Minister's institution, was a ministerial body which was unlike the U.S. Government (Koka, V.1988 pg.58).

\subsubsection{The Royal Charter of 1928}

20 In June 1928, Zog realized that was the right time to declare his monarchy, for this reason proceeded to the necessary constitutional steps. On 1 June, the President of the Republic addressed a speech in divided legislature. On June 7, the body of parliamentarians and those of the Council in a joint meeting imposed an addition to Article 141 of the Statutes with the following content: The revision of the Constitution belongs to the constitutional convention. When necessary the revision of the Constitution in accordance with the set procedure the two chambers automatically dissolved and elections held for the constitutional convention under Article 147 of the Constitution. According to this article, the election was decided to be held on 17 August 1928 with an indirect vote. Each member of the Assembly represented 15,000 thousand inhabitants and for each dam exceeded 7,500. Declaring royal regime was too close since Zog had received and approval from Italy. In mid-August in Tirana and other Albanian cities held rallies in support of the monarchy. An opportunity was also returning from Zogou Dyrracheio on August 23, 1928 (Albanian newspaper, August 24, 1928), (Fischer J. B. 1996. pg. 135).

21 On August 25, 1928 saw the first meeting of the Constituent Assembly in 1930, the time when he was elected President (Pantelis Evangelos) the constitutional assembly. On 27 August at 16.00 held the second meeting where the 
deputies swore. On 29 August held the third meeting where read all telegrams from all over Albania supported the monarchy. At the end of the meeting, an ad hoc committee to process the most important articles of the new Constitution. The committee met on 30 August 1928. On September 1, 09.00 held the fourth meeting of the Constituent Assembly, which viewed the report of the Committee, proclaimed Albania as a royal democracy and King Zog of the Albanians. At 10.00 on September 1, the Zog accepted the royal crown. The inauguration of the King held on 1 September at 17.00 (Albanian newspaper, September 2, 1928).

After three years, Albania has declared the royal parliamentary democracy. The Assembly elected by an indirect vote in the summer of 1928 on 01.09.1928 decided to elect to declare King of Albanians Ahmed Zogou, who 2.9.1928 gave the oath before the constituent assembly and shortly after, a Royal Constitution (http://sq.wikipedia.org/ wiki/Kushtetuta_e_Shqip\%C3\%ABris\%C3\%AB). The statute was based on the constitution that enshrines the monarchies of that time, especially those of Belgium and Italy were modeled on French Constitution. Some provisions are typical of various Balkan countries (Giannini, A. 1929. pg.34). A model that influenced largely was the Statute of Albertina, the kingdom of Sardinia.

The statute took effect on 1 December 1928 under the name "The fundamental statutes of the Albanian kingdom" and proclaimed Albania democratic, parliamentary and hereditary kingdom (The fundamental statute of the Albanian Kingdom, 1929). With the Articles of Association, the Assembly decided to transform it into parliament. The hereditary throne belonged to the great son of the king. The legislative body composed of a body, while the executive power vested in the President of the State, the king and the council composed of the Prime Minister and ministers. The statutes restated the principle of a body. In this way, the king controlled better powers. The Statute provided for the first time the Council of State that he was working in the legal field, preparing and overseeing the bills and regulations. This method was an imitation of the French experience. Regarding the government in the Statute provides a clean distinction between the Prime Minister and the President of the Board. The cabinet was a collegiate institution referred before the king and parliament on matters belonged to the general policy of the state. The capital of the statutes regulating the judiciary was more complete than the previous statute. He held the general principles of the activity of the courts and the judicial system provided in Albania as an independent branch. The chapter on the rights and responsibilities of citizens as the previous Statute restate the fundamental rights of these

\subsection{The constitutional law of Albania 1937-1946}

In the fascist conquest and the persecution of King Zog of Albania, a de facto constitution of 1928 ended. The partners of the conquerors gave the Albanian royal crown in another country (Italy), in this case to Victor Emmanuel III, King of Italy, act violated the Constitution of the Royal democracy (Omari L. 1994.pg.39).

\subsubsection{The Constitution of 1946}

After the liberation from the fascists and the communists coming of 1946 on 11 January 1946, the Constitutional Assembly declared Albania Democratic Republic solving in this way the question of the form of government. The end of the Second World War brought about radical changes in Albania (Dhimo, Dh. 1963 pg. 79). The state joined in the way of major changes and reforms that were communist character, which is vested with the new constitution (The Constitution of the People's Republic of Albania, 1946). The Constitution of Albania valid from 16.03.1946. After completing the task, the constitutional assembly was not dissolved, but decided to turn a simple parliament exerting its activity as a parliament.

The content of the Constitution of 1946: This Constitution had Communist character and enshrine the political power of working in alliance with the rustic class (Aurela, A. pg. 53). The provisions of the Constitution expressed openly establishing a people's democracy in Albania (The constitutional law of the Socialist People's Republic of Albania. 1983. Pg.41-49).The Constitution consisted of three parts (The Constitution of Albania Republic of Albania, Tirana, 1946).The same guarantee as an important principle of the unity of power, which took the following form: all power is concentrated in parliament and in people's councils. Those practiced as legislative and the executive. Hierarchical first instrument was the parliament, which represented the sovereignty of the nation and the state. The parliament elected its Bureau, which was the highest organ of state with permanent activity. That was essentially a collective body of the state, proclaiming laws and accept foreign ambassadors. This body had proclaimed power to the laws of folk parliament and did not exercise the right of veto.

27 In the system of judicial bodies was part of the Supreme Court, the court of prefectures and yponomarchion 
and military courts. A law could be established and courts but for special cases. The Constitution proclaiming the principle of independence of the courts and the prosecution institution of parliament as an institution for the legality

\subsubsection{The Socialist People's Constitution of Albania 1976}

The Constitution of 1946 along with the revisions made to it in 1950 was seen as the Constitution established the economic basis of socialism. In 1971, the Sixth Congress of the Socialist Party of Albania chairman (Enver Hoxha) proposed the drafting of a new constitution, which would better serve the economy, and development of the site. All editing of the text was entrusted to the Central Committee of the party. The Committee established a special committee on the drafting of the Constitution. On 12/28/1976 parliament approved by a vote of 100\% new constitution called Albania "popular socialist democracy."

The communist content of the Constitution: The Constitution deepened communist character of the Albanian state and class distinction. One difference with the previous Constitution of 1946 was that the Constitution was inspired in its entirety by ideologies and principles of Marxism-Leninism (The constitutional law of the Socialist People's Republic of Albania. 1983 pg.51). Restate the leading role of the leader, proclaimed the socialist party as the only party in the country. Also did not recognize private property, but only the collective ownership.

\section{The constitutional changes of 1990}

This party state imposed by the communists together with the lack of fundamental freedoms of man and the difficult economic situation created much resentment in people. The democratic changes in 1990 pointed the way of change and reform in the constitutional law of the country. The drafting of a new law was needed to put an end to the old practice of communism (Loloci, K. 1999 pg.4). In 1991, the first pluralistic parliament that had come out of the elections this time was unable to draft a new constitution. All political parties agreed to adopt a constitutional package, which defines the main lines of organization in the public sector. On 29.04.1991 was approved with the nr.7491/91, who imposed a democratic parliamentary system, with a head of state. The legislative power is vested in the parliament consisted of a single body. The government exercises executive power, while the President would be an instrument of political balance, with increased responsibilities (Loloci, K. 1999 pg.5).

\subsection{The Constitution of 1998}

The Constitution of Albania adopted on 21.10.1998 (Tsatsos, D.Th. - Katrougalos, G.S. 2001 pg.3). It is divided into 17 parts, which are divided into chapters. The first part of the Constitution enshrines the basic principles of the state. Article 1 establishes the following: "1.The Albania is a parliamentary democracy 2.The Republic of Albania is uniform and the state is indivisible. 3. The government of the country is based on free, equal, general and periodic elections. 'Article 2 enshrines the sovereignty of the Republic of Albania, which belongs to the people, who exercise it through their representatives elected by direct vote. In the third article of the Constitution guarantees the independence, integrity of the Albanian state, respect for basic rights and freedoms, religion. Under Article 4, the Constitution is the supreme law of the Albanian democracy whose provisions are directly applicable, except where the Constitution provides otherwise. In Article 5, the Albanian democracy applies international law, which is binding on it. Articles 7.6 establishes the government system in the country based on the separation of three powers.

Through Article 8 protected national rights of the Albanian people living abroad and performs in help. Enshrined in Article 9 of the constitution of a political party or organization, which must be consistent with democratic principles. Prohibited the establishment of political organization based on dictatorial methods. The parties are obliged to publish their expenses. In Article 10, guaranteeing the absence of any particular religion (Albanian Constitution, 21 October, 1998). Article 11 establishes the economic system based on private property and the free market. Article 12 enshrines the mission of the armed forces is to safeguard the independence and integrity of the country. Article 13 enshrines the principle of decentralization of local power and Article 14 enshrines the characteristics of the Albanian flag and the Albanian nation.

\subsubsection{Analysis of Constitution}

The basic rights and human freedoms enshrined in Part II of the Constitution, which is divided into 6 chapters from Article 
15 to Article 63 . The first chapter establishes the basic principles that underpin the basic rights and freedoms (Albanian Constitution, 1998, Article 15-20).

The second chapter of the second part establishes the rights and personal liberties (Albanian Constitution, 1998, Article 21-44). The third chapter guarantees civil rights and liberties (Albanian Constitution, 1998, Articles 45-48). The fourth chapter enshrines economic, social and cultural rights (Albanian Constitution, 1998, Articles 49-58). The fifth chapter enshrines the social objectives of the State (Albanian Constitution, 1998, Article 59). The sixth chapter enshrines the institution of the Ombudsman (Albanian Constitution, 1998, Articles 60-63). In the third part, which is divided into 4 chapters, enshrined the legislature (Albanian Constitution, 1998, Articles 64-85). The fourth part is devoted to the President of the Republic who represents the unity of the people (Articles 86-94). Defines the qualifications you need to have a candidate to be elected President. The term of office is five years with a right of renewal. Part $\mathrm{V}$ establishes the cabinet (government 95-107). The Government consists of the Prime Minister, Deputy Prime Minister and ministers. The sixth part of the Constitution enshrines the local government (Articles 108-115). The seventh part establishes administrative acts and international treaties of the country (Articles 116-123). The eighth and ninth of the Constitution establishes the Constitutional Court and other courts in the country, the powers thereof, the process of election of members, qualifications elected, incompatibility etc. (Articles 124 to 147). The tenth part enshrines the State Prosecutor, the sending of the role of the Advocate General of the State, so his choice (148-149). The eleventh part establishes the institution of referenda (Articles $150-152)$. The people (50,000 people) has the right to repeal a law and to require the President of the Republic to conduct a referendum on a serious issue. In addition, the fifth of the Members or at the suggestion of the cabinet can be decided on a referendum on a serious issue. The twelfth part enshrines the central election commission, which has the task of reviewing, address, preparation and everything else concerning the elections and after the end proclaims the results (Articles 153-154). All committee members shall enjoy immunity as senior judges in the country. The thirteenth place safeguards the public revenue of the country (Articles 155-161). The fourteenth part establishes the Court, which is the supreme organ of the state budget (Articles 162-165). The President of the Court is elected by the parliament with a proposal of the President of the republic. The term of office is seven years. Article 163 establishes the powers of the Court. The fifteenth part enshrine the armed forces (Articles 166-169). The President of the Republic is the head of the armed forces. The National Security Council is an advisory body to the President. The sixteenth part of the Constitution enshrines the imposing emergency measures when there is war or a natural disaster (Articles 170-176). The seventeenth part of the Constitution enshrines the process of revising the Constitution (Article 177). The initiative for the revision has the fifth Members. No review can be done during the term of the emergency measures. The eighteenth is the last part of the Constitution and enshrine some transitional provisions.

\subsection{Constitutional Court}

The democratic changes that occurred in the early 90 s marked a radical change in the history of the Albanian state and its institutions (Omari, L. 2006. Pg.49). The democratic direction of the state demanded a series of reforms that would help in establishing the rule of law and respect for human rights. The basic principles followed these republics proclaimed originally by n.7491 dated 29.04.1991 for basic constitutional provisions and then continued with n.7561 of 04/29/1992 on basic constitutional provisions require the adoption of other acts to regulate the operation. The Constitutional Court is composed of nine members, five of whom were elected by the parliament and four by the President of the Republic. The President of the Constitutional Court are elected by secret ballot by the members themselves. The senior law determines the status of a constitutional court, responsibilities of, the power of his decisions.

On 15.07.1998 parliament approved the n.8373 on the organization and functioning of the Constitutional Court of Albania, who created a legal basis for the themes of the Constitutional Court. On 28.11.1998 applied the Constitution of Albania in which the Constitutional Court had an important part to constitutional provisions. Changes were and how to define the judges, their competence and underlying steps that move to the Constitutional Court. The President with the consent of parliament appoints judges for a nine-year term (Albanian Constitution, 1998, Article 125, par.1-2). The judges cannot anadioristoun. The Constitution required the adoption of legal instruments for the implementation, consistently on 10.02.2000 parliament to approve the 8577 Law "For the organization and functioning of the Constitutional Court of Albania", which was designed by the Venice Commission "Democracy through the law." This law regulate such issues, eg way of application, the preliminary investigation, litigation procedures, capacity and mandate of the judge.

In conclusion, the activity of the court is divided into two periods. From its establishment until today, the court proceedings were rising and viewed from the cases that have been tried: 
Affairs hearing of cases in all 92 ....................... 12

Affairs hearing of cases in total to' $93 . . . . . . . . . . . . . . .13$

Affairs hearing of cases in all 94 ...................... 11

Affairs hearing of cases in total to' $95 \ldots \ldots \ldots \ldots . . . . . .16$

Affairs hearing of cases in all 96 ........................ 46

Affairs hearing of cases in all 97 ....................... 62

Affairs hearing of cases in all 98 ........................ 79

Affairs hearing of cases in all 99 ........................ 67

Affairs hearing of cases in the entire '00 ..............96

Affairs hearing of cases in all the 01 ..................213

Affairs hearing of cases in all the 02 ..................243

Affairs hearing of cases in total to'03 ................ 279

Affairs hearing of cases in total to'04 ................ 210

Affairs hearing of cases in total to' 05 .................256

Affairs hearing of cases in all the 06 .................251

Affairs hearing of cases in all the 07 .................222

Affairs hearing of cases in the whole 08 ..................... 171

\subsubsection{Functions}

The Constitutional Court of Albania is not included in the simple judicial system of this country. Based on Article 124 of the Constitution that is competent for constitutional review of laws and administrative acts. Guaranteeing respect for the Constitution and gives the final interpretation of this. In the exercise of its operation, that (court) always operates according to the rules of the Constitution (Article 124 paragraph 2 of the Constitution). The powers of the court under Article 131, under which that body decide on:

1) The contrast of laws against the Constitution or international agreements as provided for in Article 122 of the Constitution. The incompatibility of international agreements with the Constitution from being ratified.

2) The incompatibility of administrative acts with the Constitution and international treaties.

3) Disputes relating to the responsibilities between the powers of local authorities and the government.

4) The constitutionality of political parties, other political organizations, and their activity under Article 9 of the Constitution.

5) The resignation from office of the President of the Republic and the certification of the inability of his powers.

6) The issues relating to eligibility and incompatibility in the exercise of the functions of the President and Members and certification of election.

7) The constitutionality of the referendum and certify the results.

8) The final adjudication of complaints of individuals for violation of their constitutional rights to a fair trial, after exhausting all legal remedies.

The Constitutional Court decide on the constitutionality of:

1) the decision of parliament for the discharge of the President (Article 90 Fri the 3rd, 91 paragraph 2 of the Constitution).

2) of Parliament's decision to exempt judges of the Supreme Court (Article 140 of the Constitution).

3) the government's decision to exempt mayors (Article 115 of the Constitution).

4) the prosecution of a judge of the Constitutional Court (Article 126 of the Constitution) and the Supreme Court (Article 137 paragraph 2 of the Constitution).

\subsubsection{The faces that move the process to the Constitutional Court}

The proceedings before the Constitutional Court shall initiate the following subjects: 1) the President, 2) The Prime Minister, 3) One-fifth of MPs, 4) The President of the Court of Auditors, 5) Courts under Article 145 even .2 of the Constitution, 6) the Ombudsman, 7) the institutions of central government, 8) the organs of religious communities, 9) political parties and other organizations, and 10) individuals.

Applications that come to court shall proceed as follows: the President of the court shall transfer the application after its registration, to a judge, who is preparing the report and related documents for the preliminary 
investigation of the case (Omari L. 2002. pg.48). The Rapporteur presented the case to a board of three members. The Board shall decide on the acceptance of the application, ie whether it should be passed or not. If no consensus hypothesis presented at the meeting of judges decide by a majority of votes. The case cannot be passed for consideration when the object is not subject to the jurisdiction of the court or where the applicant is not entitled to start the process (Omari, L. 2006 .pg.39).

At the end of the examination of the case, the Constitutional Court expressed Decision: Decisions of the Constitutional court is justified in writing and are effective after publication in the official journal, except where the Constitutional Court decides otherwise. The court rulings are final and applied by all the institutions of government and not disputed by anyone (Article 132 paragraph 1 of the Constitution) (Omari L. 2002. pg.51). Normally Constitutional Court decisions are not retroactive. However, the law provides some exceptions: When it comes to decisions that remove criminal decisions in the phase of their execution, decisions interpreting the Constitution, are decisions that have not reached the achievement of legal consequences and court decisions that are not final

\subsubsection{The Composition}

The Constitutional Court consists of nine members appointed by a nine-year term. The President with the consent of parliament appoints the constitutional judges. The third of judges every three years. Those must have higher education and 15 years experience. The President appoints the President for three years with the right of renewal (Article 125 of the Constitution). The judges enjoy immunity and cannot be prosecuted without the consent of the tribunal (Article 126 of the Constitution). In addition, they may be exempted under the circumstances provided for in Article 128. Also, the office of judge is incompatible with any other public office or private activity (Article 130 of the Constitution). The term of office of a judge ends:

1) When ordered by a final decision.

2) When not perform his duties for six months without reason.

3) After completing 70 years of age.

4) Once resign.

5) When declared inability exercise tasks.

\section{Conclusion}

The analysis in this article is understood that now Albania has become a developed and modern constitutional order. The content of the Constitution gives to it the prestige of a State that respects the constitutional rights of citizens and foreigners living in Albania. The Constitution of Albania also recognizes the independent principles as enshrined in it. Lists in a proper way the powers of the President, the Cabinet and the Prime Minister. Enshrines the principle of popular sovereignty and the separation of powers as the basic principles governing the constitutional law of the country. Recognizes the rights of the minority who can use their own language and customs. In addition, the institution of the Constitutional court has helped the law to analyze and provide answers to complex issues, which was previously unclear. The setting of the composition and powers of the court in the Constitution gives to this institution a major prestige.

\section{References}

Reso, R. (1978). The introduction of the project "Albania what it was, what is and what will be done with this",Pristina.

Luarasi, A. (1994). "Customary law in Albania".

Frasheri, S. (1889). "Albania what it was, what is and what will be done".

Omari, L. (1994). "The parliamentary system", Tirana.

Gjilani, F. (1927). "The Statute of Albania".

Anastasi, A. (2004)."The constitutional law".

Fischer, J. B. (1996). "King Zog". Tirana.

Koka, V. (1988) "The birth there the evolution of dictatorial monarchy in Albania from 1912 to 1939". No. 3.

The fundamental statutes of the Albanian kingdom, Tirana, 1929.

The fundamental statutes of the Republic of Albania, Tirana, 1925, the official newspaper of the state, No. 8 3/7/1925.

Giannini, A. (1929). "The Constitution of Albania project Constitutions of the countries of the Balkans", Rome.

Dhimo, Dh. (1963). "The Constitutional Law of the People's Republic of Albania", Tirana.

The constitutional law of the Socialist People's Republic of Albania, a group of writers, Tirana, 1983.

The Constitution of Albania Republic of Albania, Tirana, 1946. 
Loloci, K. (1999). "The new Constitution and a few problems at the beginning of its implementation", Legal magazine, Tirana. Tsatsos, D.Th. - Katrougalos, G.S. (2001)."The Constitution of the Republic of Albania".

Kushtetuta e Shqipërisë (Albanian Constitution), 21 October 1998.

Omari, L. (2006) "Principles and Institutions of Public Law".

The Statute of the Albanian state in 1922.

\section{Periodicals}

Albanian newspaper, August 24, 1928.

Albanian newspaper, September 2, 1928.

Albanian legislation and similar laws.

\section{Internet Sources}

http://sq.wikipedia.org/wiki/Kushtetuta.

http://sq.wikipedia.org/wiki/Kushtetuta_e_Shqip\%C3percentageABrispercentage C3\% AB.

http://www.gjk.gov.al. (Page Constitutional Court). 